\title{
A generic key to the known larval Elmidae (Insecta: Coleoptera) of French Guiana
}

\author{
William D. Shepard'; Simon Clavier² \& Axel Cerdan ${ }^{3,4}$ \\ 1 University of California Berkeley, Essig Museum of Entomology. Berkeley, California, United States. \\ ORCID: http://orcid.org/0000-0003-4664-2597. E-mail:William.Shepard@CSUS.edu (corresponding author) \\ ${ }^{2}$ ONIKHA. Kourou, French Guiana. ORCID: http://orcid.org/0000-0001-7964-1131. E-mail: clavier.simon@gmail.com \\ ${ }^{3}$ Laboratoire EDB (UMR 5174: CNRS, Université Toulouse 3 Paul Sabatier, IRD), Université Paul Sabatier. Toulouse, France. \\ ${ }^{4}$ CNRS, UMR EcoFog (AgroParisTech, CIRAD, INRA, Université des Antilles, Université de Guyane), Kourou Cedex, France. \\ ORCID: http://orcid.org/0000-0002-5195-3720. E-mail: Axel.Cerdan@ecofog.fr
}

\begin{abstract}
An identification key is provided for 21 larval types of Elmidae (riffle beetles) known to occur in French Guiana. Not all elmid genera known to occur in French Guiana are known in the larval stage. Nor are all the known larval types assigned to known elmid genera.
\end{abstract}

Key-Words. Biodiversity; Identification; Immatures; Neotropical; Survey.

\section{INTRODUCTION}

More and more political units are conducting surveys of their freshwater invertebrate taxa as a way of assessing in-stream water quality. In these assessments, better and better results depend on using the lowest level of accurate identifications. Generic identifications have become the state-ofthe-art for many invertebrates, given the keys that are available (e.g., Dominguez \& Fernández, 2009; Hamada et al., 2018), especially for immature stages. However, keys for immature stages are often incomplete in the sense that not all genera are known in the immature stages. And many smaller political units do not have a through survey of their invertebrate fauna upon which to base their identifications. So, more survey work needs to be conducted. For many years, freshwater faunal surveys in French Guiana have been conducted by HYDRECO (Laboratoire Environnement de Petit Saut). Among other products, these surveys resulted in a collection of identified specimens. Additional surveys of adult Elmidae were conducted independently by Pierre Queney from 2003 to 2010 which resulted in a list of the 18 elmid genera known from French Guiana and a key for adult identification at the generic level (Queney, 2012).

Work is ongoing to identify the larval elmids of South America. Manzo \& Archangelsky (2008) produced a key to all Elmidae larvae known at the generic level by 2008. But their key only accounted for $56 \%$ of known South American genera. This has been followed by descriptions of the lar- vae of Gyrelmis Hinton (González-Córdoba et al., 2018b) and Stenhelmoides Grouvelle (GonzálezCórdoba et al., 2018a), and the association of adults and larvae of Hintonelmis Spangler using barcoding (Fernandes et al., 2013). One of the major challenges is that undescribed elmid genera (as evidenced by adults) keep being found in South America (Barr, 2018). André S. Fernandes (pers. com.) reports eight undescribed genera from Brazil alone! And undescribed and unassociated elmid larval types keep being discovered as well. Plus, there is the possibility of intrageneric variation, as has been found in other elmid species (Glaister, 1999; Archangelsky \& Brand, 2014), although sometimes what looks like intrageneric variation is a signal of cryptic, undiagnosed genera (Brown, 1977). So there will be much work to be done with South American larval Elmidae for a very long time.

When collecting elmids in the Neotropics, it is common to find larvae that have not yet been associated with an identified adult. This limits information that might be useful for assessing water quality and may give a false impression of elmid diversity. The identification of unknown larvae can sometimes be made by identifying adult genera collected at one site and then matching up known larval identifications with those adults. The remaining adults and larvae can then be associated. This is sometimes hazardous because one cannot always be sure that all adult and larval morphs can be collected at one site. But by doing this at multiple sites, the validity of adult/larval associ-
Pap. Avulsos Zool., 2020; v.60.special-issue: e202060(s.i.).15 http://doi.org/10.11606/1807-0205/2020.60.special-issue.15 http://www.revistas.usp.br/paz

http://www.scielo.br/paz

Edited by: Sônia A. Casari / Gabriel Biffi

Received: 26/10/2019

Accepted: 17/01/2020

Published: 04/03/2020
ISSN On-Line: 1807-0205

ISSN Printed: 0031-1049

ISNI: 0000-0004-0384-1825 
ations can be enhanced. Another way larval identifications can be achieved is by rearing larvae to adulthood. Rearing immature stages is useful for establishing both generic and species-level identifications. Final instar larvae can be placed in a sealable plastic container with wet sand and a small stone or piece of wood. If the larva is sufficiently developed, it will burrow under the stone or wood, pupate and transform into an adult within a few weeks. Final instar larvae can be recognized by the presence of spiracular tubercules on the lateral sides of the mesothorax and abdominal segments I-VIII. Alternatively, pupae found in the stream-side environment can be held in the same kind of containers until they transform into adults. The key is to maintain a humid environment so the larvae or pupae do not desiccate. However, it is difficult to find pupae in nature. Specific directions on rearing can be found in White \& Jennings (1973), Glaister (1985), and Davis (1986).

A few years ago the first author was asked to produce an identification key for the larval Elmidae of French Guiana, which led to this paper. It is hoped that this key will increase the quality of identifications made by water-quality assessment scientists, and that this key will encourage other workers in French Guiana to pursue further studies with Elmidae. As with other keys, this one should be considered preliminary. It is intended to be used in French Guiana but it might also be useful in neighboring countries.

\section{MATERIAL AND METHODS}

An intense survey for both adult and larval elmids was conducted during February 2016 and March 2019, by WDS, Cheryl Barr and Simon Clavier. Concurrently, Axel Cerdan was conducting stream benthic studies in the same area. Both studies yielded specimens for this work. Additionally, the HYDRECO collections were searched for other elmid larvae. Specimens used in this study are deposited in the collections of HYDRECO and Essig Museum of Entomology, University of California.

Abbreviations used in the text include the following: $A B=$ abdominal segment; $I-I X=$ the individual abdominal segments, from one to nine; HYDRECO = Laboratoire Environnement de Petit Saut, BP 823, 97388 Kourou cedex, French Guiana.

Photographs of elmid larvae produced at the California Academy of Sciences (see Acknowledgments) used a Syncroscopy Auto-Montage system. Photographs produced at the EcoFog lab used a Leica dissecting microscope (Z16APO) fitted with a Leica camera (DC450) and Helicon focus-stacking software. Images were manipulated using Photoshop CC (version 14; Adobe Systems, San Jose, CA). All photographs are of larvae collected in French Guiana. Because the photographs are of actual larvae and the characters vary in size, not all characters show in all photographs.

Larval morphology follows that in Manzo \& Archangelsky (2008) and Segura et al. (2011). The line drawings in Manzo \& Archangelsky are particularly helpful.

\section{RESULTS}

Twenty-one types of elmid larvae have been collected as of March, 2019. All are included in the key. Five genera known to occur in French Guiana have not had larvae associated with them. They include: Amazonopsis Barr, Pagelmis Spangler, Pilielmis Hinton, Portelmis Sanderson and Tyletelmis Hinton. Five larvae have yet to be associated with any genus. They were assigned letters. They include: larva V, larva W, larva X, larva Y and larva Z.

\section{Key to the larval Elmidae known from French Guiana}

1. Pleural sclerites on AB I-VIII; body strongly flattened dorsoventrally; lateral margins of thoracic and abdominal segments with narrow, falcate extensions (Fig. 1).

Phanocerus Sharp

1.' Pleural sclerites not as above; body cylindrical, subcylindrical or slightly flattened dorsoventrally; lateral margins of thorax and abdomen without narrow, falcate extension .cylloepus Erichson

2. $A B$ IX with pleural sutures extending to middle; body cylindrical (Fig. 2)

2.' AB IX lacking pleural sutures; body cylindrical, subcylindrical or slightly flattened.

3. $A B I X$ broad, flat, with denticulate lateral margins, tergum with midline row of about six spines (spines may be broken off) (Fig. 3) .................................Larva $V$

3.' ABIX not as above....

4. Sensory appendage of second antennomere very long, equal or exceeding length of second antennomere; $A B I X 2.5 \times$ as long as wide; a line of flat, wide tubercles on each side of midline on mesonotum to $A B$ IX; posterior margins of pronotum to AB VIII with row of stout tubercles; $A B$ I-VIII with slightly expanded sides (Fig. 4).. Austrolimnius Carter \& Zeck

4. Not with the above combination of characters

5. Abdominal terga with two pairs of flanges extending above surface (Fig. 5) ........................................................................................... Neolimnius Hinton

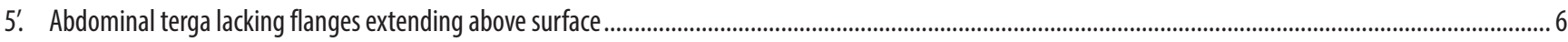

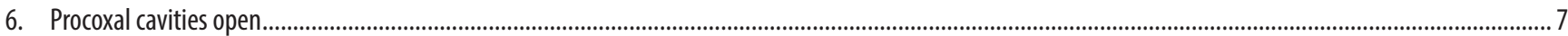

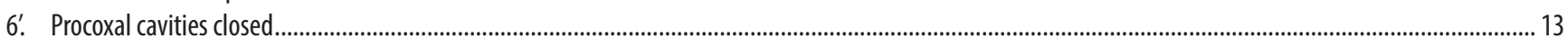

7. Mesonotum to AB VIII with dorsal, transverse, broad ridge on posterior border; AB I-VII with posterolateral corners projecting posteriorly; abdominal segments lacking pleurites; $A B$ IX pentagonal in cross section (Fig. 6) ..... Larva W

7. Mesonotum to AB VIII lacking transverse ridge; $A B$ I-VII lacking posterior projections; some abdominal segments with pleurites; $A B$ IX not pentagonal in cross section. 
8. Only $A B$ I with pleurites 9

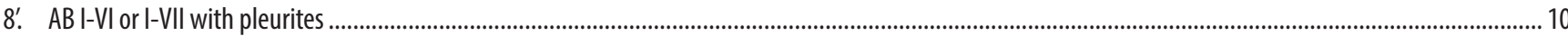

9. Lateral sides of AB I-VI extended as quadrate projections; projections laterally denticulate; surfaces not heavily tuberculate; anterior of head lacking blunt, stout

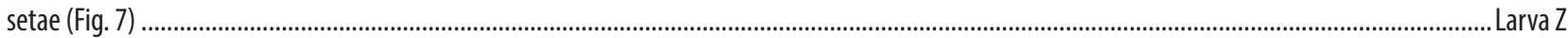

9. Lateral sides of AB I-VI lacking quadrate projections; all surfaces heavily tuberculate; meso- and metasternite with heavily tuberculate triangular projection between coxae; body cylindrical; anterior of head with numerous blunt, stout setae (Figs. 8-9) Stenhelmoides Grouvelle

10. Pleural sclerites present on ABI-VII 11

10 '. Pleural sclerites present on $A B I-V I$ 12

11. Body wide, heavily sclerotized, densely pubescent; $A B I X, 2.2 \times$ as long as wide (Fig. 10) .. Potamophilops Grouvelle

11. Body slender, not heavily sclerotized, not densely pubescent; $A B I X, 5 \times$ as long as wide (Fig. 11) Elachistelmis Maier

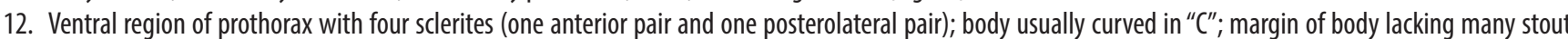
spines (Fig. 12) Xenelmis Hinton

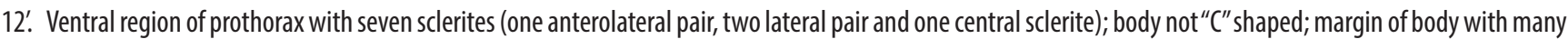
stout spines (Fig. 13)

Stegoelmis Grouvelle

13. Lateral margins of prothorax to AB I overhanging venter of those segments; all surfaces smooth, not tuberculate; body wide anteriorly and tapering posteriorly (Fig. 14).

Gyrelmis Hinton

13'. Lateral margins of prothorax to AB I not overhanging those segments; surfaces tuberculate; body not wider anteriorly ....................................................... 14

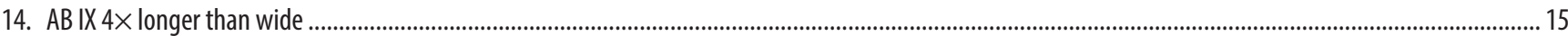

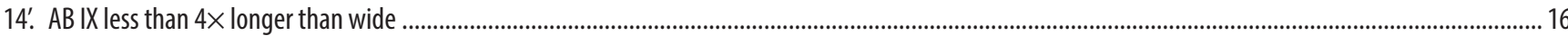

15. Thorax and abdomen dorsally with tubercles arranged in rows (Fig. 15) ................................................................................................ Hexacylloepus Hinton

15'. Thorax and abdomen with tubercles randomly arranged (Fig. 16)...................................................................................................................eoelmis Musgrave

16. Dorsum with tubercles; venter of prothorax with several separate sclerites................................................................................................................ 17

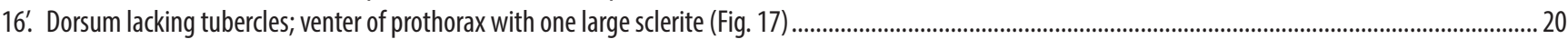

17. $A B I X$ with one lateral row of spines on each side (Fig. 17) ............................................................................................................................... Heterelmis Sharp

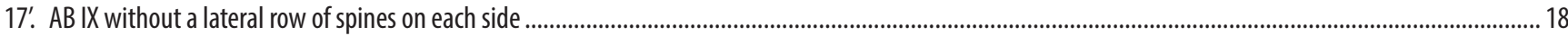

18. Midline of dorsum with a longitudinal row of yellow spots at intersegmental joints; anterior margin of head lacking large tooth between bases of antennae and clypeus (Fig. 18) Microcylloepus Hinton

18. Midline of body lacking dorsal longitudinal row of yellow spots; anterior margin of head with a large tooth on each side, between bases of antennae and clypeus...

19. Body flattened in cross section; mesothorax and metathorax with 2 pleurites; prothorax with distinct suture between coxal cavities and notum (Fig. 19) ........... Macrelmis Motschulsky

19'. Body semicylindrical in cross section; mesothorax and metathorax with 3 pleurites; prothorax lacking suture between coxal cavity and notum (Fig. 20) ............ Hintonelmis Spangler

20. Prothorax venter with one large sclerite (Fig. 21) . ..Larva $Y$

20. Prothorax with pentagonal prosternum; two pleurites, anterior pleurites meeting at midline, posterior pleurites wrapping around coxal cavities (Fig. 22) ..........

...Larva X

\section{Characteristics of elmid larvae not associated with a known genus}

\section{Larva V (Fig. 3)}

Length $3.9 \mathrm{~mm}$. Body semicylindrical; dark brown, with lighter yellow-brown spots beside ecdysal suture, apex of AB IX yellow; surface covered with white tubercles. Head globular, transverse line of long white setae on frons; frontoclypeal apex with short yellow setae. Antennae with sensory appendage of second antennomere equal to length of third antennomere. Labial and maxillary palpi very short. Labrum shiny and smooth. No teeth on margin of head medial to antennae. Ecdysal suture extending from pronotum through $A B$ I. Pronotum in basal half with oval smooth area devoid of tubercles on each side of ecdysal suture; anterior border and anterolateral corners with long white setae; lateral margins serrate. Pronotum to $A B$ VIII with posterior margins with long setae. Mesonotum to $A B$ IX with basal $1 / 3$ to $1 / 2$ narrower than apical $1 / 2$ to $2 / 3$, capable of telescoping into preceding segment; lacking white tubercles. Prothorax with three ventral sclerites on each side (1 broad anterior sclerite, 1 very elongate triangular lateral sclerite, 1 posterolateral subtriangulalr sclerite); procoxal cavities open. Meso- and metasternite broad and flat; each with two linear pleurites on each side; meso- and metacoxal cavities open. AB I-V with anterolateral corners with linear sclerotized ridge that meets tooth from preceding segments; posterolateral corners with short tooth. $A B$ I with narrow, linear pleurite. $A B$ II-IX lacking pleurites or pleural sutures. $A B$ IX broad, flat; with spinose lateral ridges; mid-dorsal line of about 6 erect spines (easily broken off); ventral operculum subpentagonal, not reaching sides of segment.

\section{Larva W (Fig. 6)}

Length $4.5 \mathrm{~mm}$ (mature larva). Body brown; comma-shaped after fixation; well sclerotized, heavily granulate; widest in pronotum and mesonotum. Head with frons flattened and well sclerotized, fitting flush into pronotal opening; remainder of head lightly sclerotized. Antennae with short sensory appendage on second an- 
tennomere. Pronotum on each side with five depressions (one broad basal depression, one depression to side of middle area, one depression near anterolateral corner, one elongate depression on anterolateral corners, one small depression on posterolateral corner); middle area broadly raised; posterior border arcuate. Mesonotum with posterior half raised in broad, rounded ridge extending between posterolateral corners; posterolateral
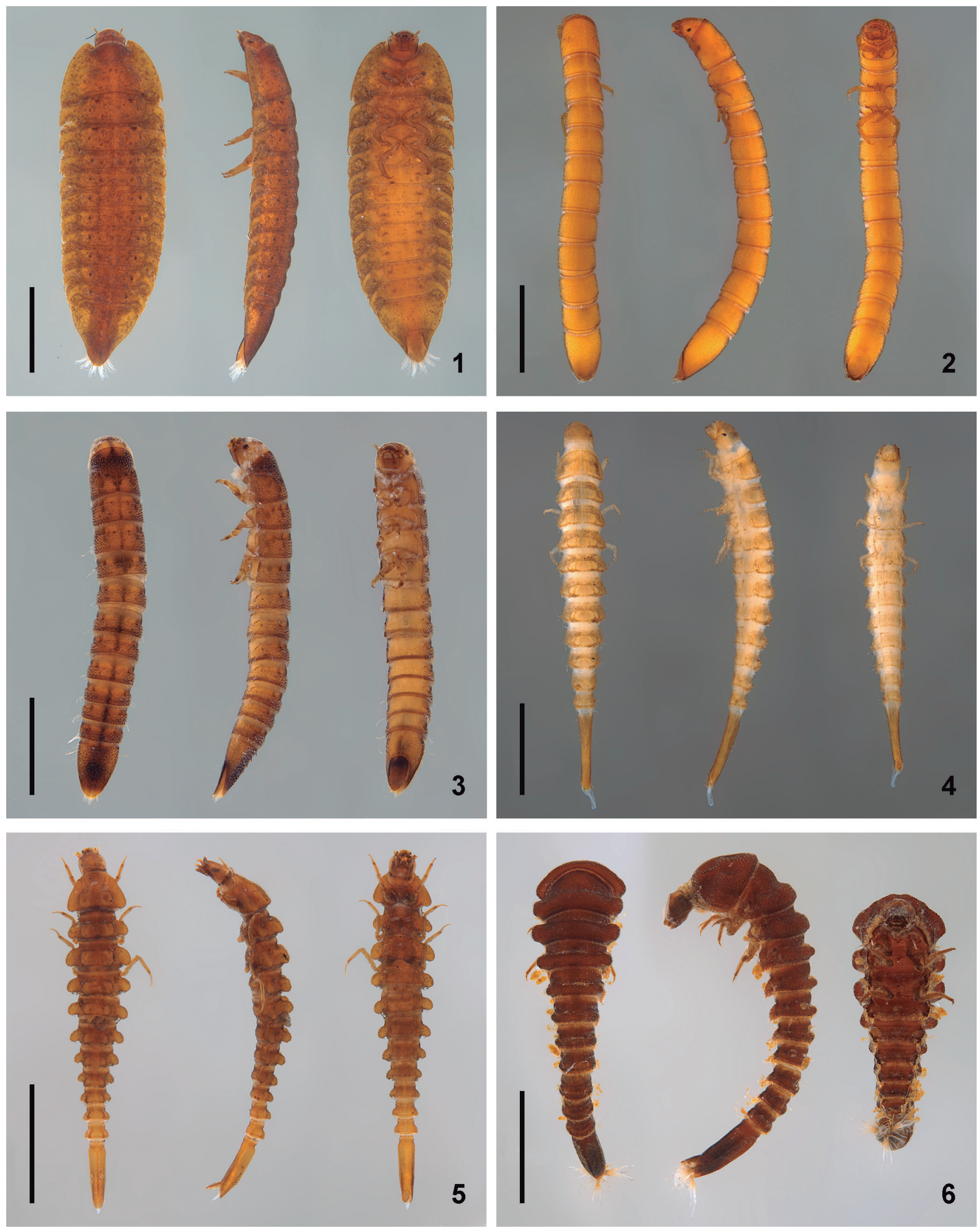

Figures 1-6. Larval habitus (dorsal, lateral, ventral). (1) Phanocerus Sharp; (2) Cylloepus Erichson; (3) Larva V; (4) Austrolimnius Carter \& Zeck; (5) Neolimnius Hinton; (6) Larva W. Scale bars $=1 \mathrm{~mm}$. 
corners of ridge raised into a bump. Metanotum similar except ridge more distinct; slight notch at midline; posterolateral corners slightly produced posteriorly, with serrate margin. AB I-VIII dorsally similar to metanotum ex- cept posterolateral corners more strongly produced and extending ventrally; corners with several spines. AB IX $3 \times$ as long as wide; with middorsal ridge, two lateral ridges and two ventrolateral ridges, pentagonal in cross sec-
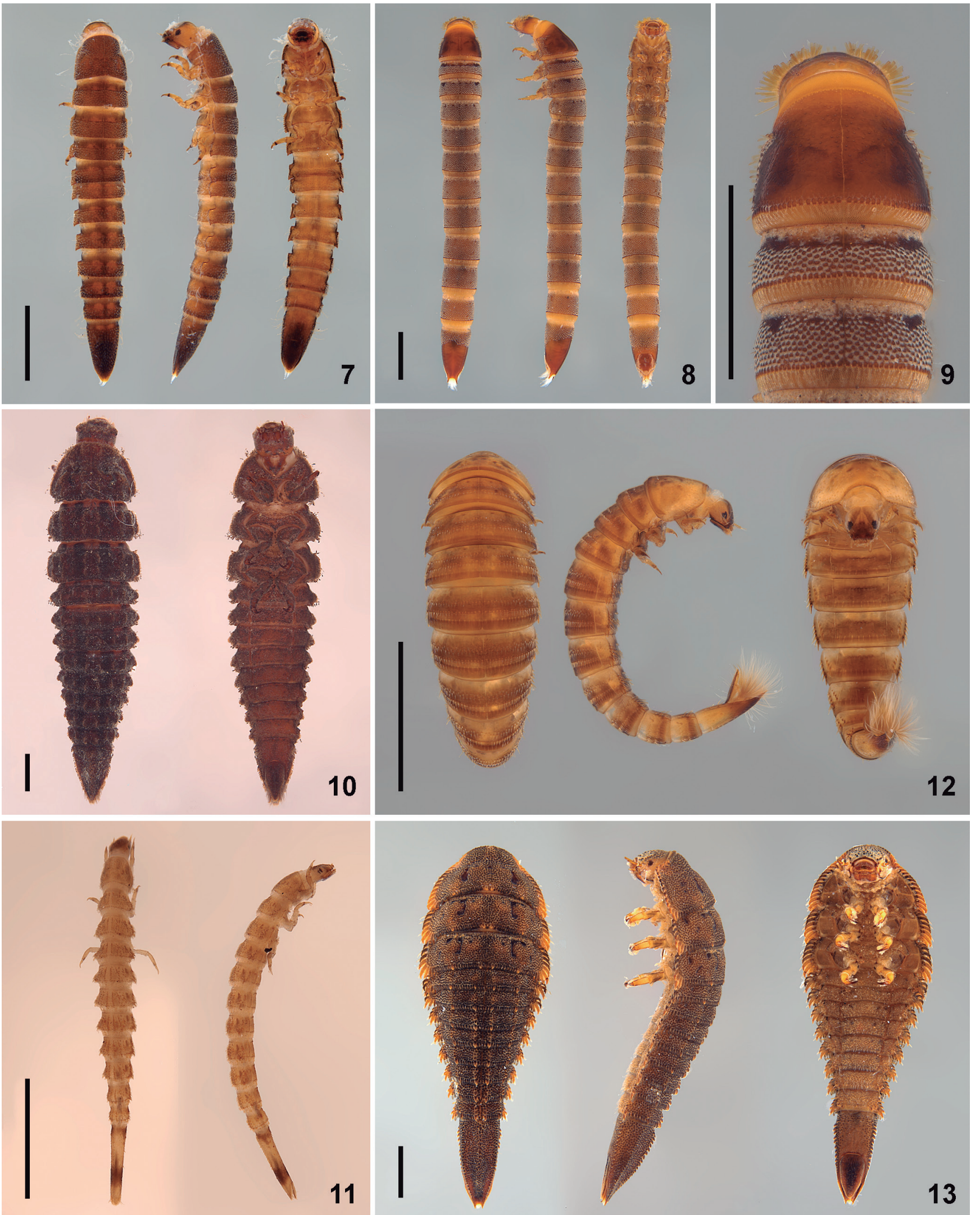

Figures 7-13. Larval habitus. (7) Larva Z, dorsal, lateral, ventral; (8) Stenhelmoides Grouvelle, dorsal, lateral, ventral; (9) Stenhelmoides Grouvelle, head and thorax, dorsal; (10) Potamophilops Grouvelle, dorsal, ventral; (11) Elachistelmis Maier, dorsal, lateral; (12) Xenelmis Hinton, dorsal, lateral, ventral; (13) Stegoelmis Hinton, dorsal, lateral, ventral. Scale bars $=1 \mathrm{~mm}$. 
tion. Prosternum with anterior pleurites serrate anteriorly, broadly meeting at midline; lateral pleurite very elongate, on inside of heavy tergopleural ridge; coxal cavities open. Intersegmental area with very short but wide, scle- rotized fold extending from side to side. Mesosternum short, very broad; very small, tooth-like projection between coxae; coxal cavities open. Intersegmental sclerotized fold present. $A B$ I sternum broadly rectangular;
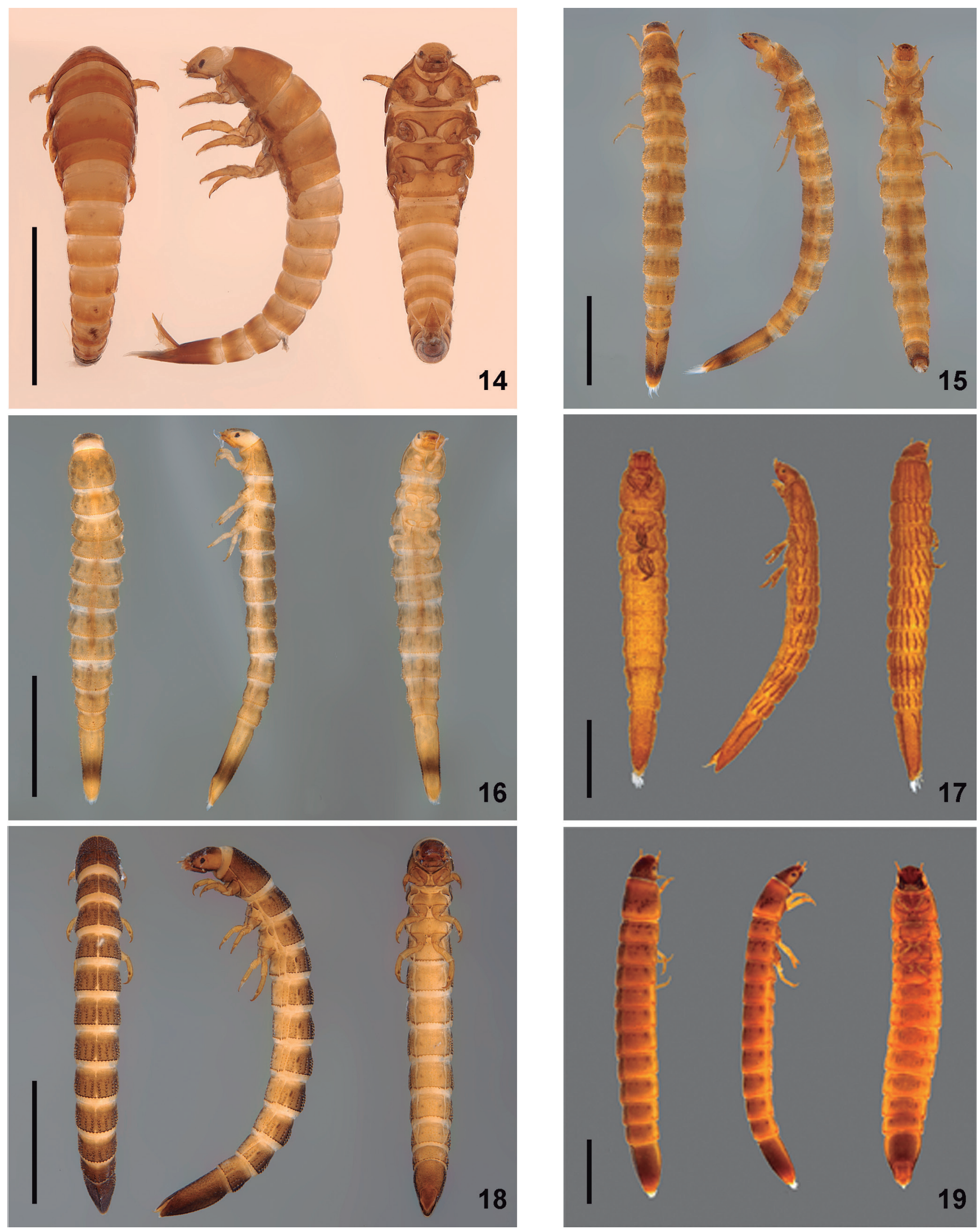

Figures 14-19. Larval habitus (dorsal, lateral, ventral). (14) Gyrelmis Hinton; (15) Hexacylloepus Hinton; (16) Neoelmis Musgrave; (17) Heterelmis Sharp; (18) Microcylloepus Hinton; (19) Macrelmis Motschulsky. Scale bars $=1 \mathrm{~mm}$. 
carina on midline; posterolateral corners produced into ventrally and posteriorly directed tooth, tooth well sclerotized, with serrate margin. $A B I I-V I I I$ sterna similar except with no carina on midline. $A B$ IX with ventrolateral
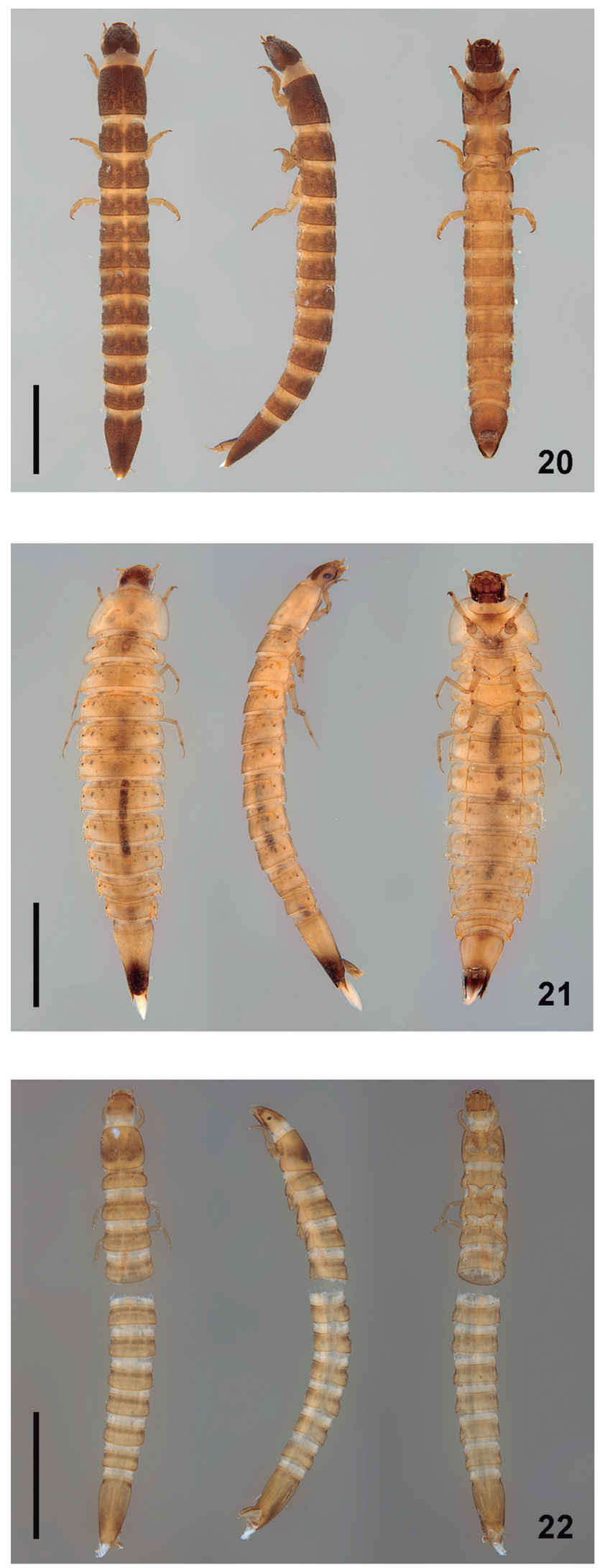

Figures 20-22. Larval habitus (dorsal, lateral, ventral). (20) Hintonelmis Spangler; (21) Larva Y; (22) Larva X. Scale bars $=1 \mathrm{~mm}$. ridges serrate; short, ventral operculum. Abdominal segments without pleurites.

\section{Larva X (Fig. 22)}

Length $3.8 \mathrm{~mm}$; width $0.4 \mathrm{~mm}$. Body color yellow; prothorax to $A B$ VIII with basal brown ring; $A B$ IX brown apically. Body semicylindrical; dorsum lacking tubercles. AB IX twice as long as wide; widest just after base; apex with two very small blunt spines with wide flat border between spines; equilaterally triangular in cross-section; well-developed flat-topped middorsal ridge. Prothorax with broadly pentagonal prosternum; two pleurites, anterior pleurite extending to middle of prothorax; posterior pleurite wrapping around posterior coxal cavity, suture between pleurites angling anteriorly from lateral edge of coxal cavity; procoxal cavities closed. Meso- and metasternite broad, rounded on sides; short triangular projection; two pleurites present; meso- and metacoxal cavities open. Metasternum and $A B$ I with median longitudinal carina in basal $1 / 2$. AB I-VII with pleurites; pleurite VII triangular.

\section{Larva Y (Fig. 21)}

Length of mature larva $4.7 \mathrm{~mm}$; width $1.0 \mathrm{~mm}$. Body flat, tan; head and apical $1 / 3$ of $A B$ IX brown; each side of segments with 1-3 brown spots. Antennae with antennomere 2 sensory appendage equal in length to antennomere 3. Dorsal midline suture from prothorax to AB VII. Tubercles absent on all surfaces. Pronotum widest basally, sides broadly arcuate; anterior and posterior borders straight; anterior and posterior angles rounded. Posterolateral corners of prothorax to AB VIII denticulate. Meso- and metanotum with straight transverse carina at basal $1 / 4$; sides arcuate; posterior corners right-angled. $A B$ I-IV similar to metanotum. AB V-VIII similar to AB IV but narrower and posterolateral corners spine-like. $A B I X$ widest at basal $1 / 6$ then converging apically; apex with two acute sines and a broad straight margin between spines. Prothorax venter fused into one sclerite; median suture in posterior $2 / 3$, extending between coxae; procoxal cavities closed; median carina from base to apical $1 / 3$. Mesoand metasternum twice as wide as long; anterior border straight; posterior border V-shaped, extending around coxae and projecting posteriorly; two broad, quadrate pleurites on each side; coxal cavities open. Pleurites on $A B$ I-VII; AB VII triangular, others quadrate. All legs with coxae as long as femura; coxae twice as long as wide; single tarsal claw long and thin.

\section{Larva Z (Fig. 7)}

Length $3.7 \mathrm{~mm}$. Body semicylindrical in cross section; brown. Head withdrawn into prothorax; labrum shiny brown; antennae with globular first antennomere, elongate second and third antennomeres, sensory appendage of second antennomere longer than third antennomere. Pro-, meso- and metanota with bare spot on each side of midline; AB I-VIII with dark median spot. Pronotum 
to $A B$ VII with lateral margin with line of stout tubercles. Ecdysal suture on pronotum to $A B$ I. Mesonotum to $A B$ VII dorsum with anterior half transversely striate, posterior half tuberculate; lateral edges produced forming quadrate flanges. Mesonotum to $A B$ VI with posterolateral corner spinulate. Lateral margins of body with long silky setae. Prosternum with 2 pleurites on each side, anterior pleurites broad, meeting at midline; lateral pleurites elongate, circling around lateral part of coxae; no prosternum. Meso- and metasternum on each side with 2 pleurites, anterior pleurite longer than posterior pleurite; sternum broad, three times as wide as long. AB I with small triangular pleurite on each side.

\section{DISCUSSION}

This study covers 21 larval types of elmid larvae (16 identified to genus and five not) known to occur in French Guiana as of March, 2019. Undoubtedly more types will be discovered, especially as more collecting is done in the southern part of the country and on and around the inselbergs.

Additionally, increased collecting will likely disclose elmid genera that currently are not known to occur in French Guiana but do occur in neighboring countries. Thus the key provided here will be modified and expanded in the future as more collecting is done and barcoding of adults and larvae is accomplished. It should go without saying that just about any identification key for South American elmids (adults or larvae) is preliminary until the elmid fauna is known better (see "Limitations" in Benetti et al., 2018). Also, anyone attempting to identify South American elmids should not make identifications using keys for North American elmids. Doing so will lead to many misidentifications (Sonderman, 2013).

\section{ACKNOWLEDGMENTS}

Collecting and export permits for the first collection trip in French Guiana were made available from the Collectivité Territoriale de Guyane according to the DIAG project (Convention № APA-973-13). Hydreco Guyane, Office de l'Eau de Guyane, Direction de l'Environnement de l'Aménagement et du Logement de Guyane, and Parc Amazonien de Guyane are thanked for providing financial and technical support. The second collection trip in French Guiana was part of the RECOLT project conducted under the National Inventory of the Natural Heritage (www.inpn. mnhn.fr). This work was conducted through the company ONIKHA and is part of the DIAG project. It received financial support from UMS PatriNat (AFB, CNRS, MNHN). Some of the larval photographs were produced by Rachel DiazBastin (California Academy of Sciences, San Francisco). This work has benefited from an "Investissement d'Avenir" grant managed by Agence National de la Recherche (CEBA, ref. ANR-10-LABX-25-01). We are pleased to make this contribution in honor of Dr. Cleide Costa in recognition of her prolific research into aquatic beetles. We thank the reviewers and editor who made suggestions that made the text more accurate and useful.

\section{AUTHOR CONTRIBUTIONS}

William D. Shepard collected specimens in the field, identified larvae and wrote the text.

Simon Clavier suggested the topic, arranged collecting expeditions, collected specimens in the field, identified specimens and produced many of the photographs.

Axel Cerdan collected specimens in the field, identified specimens and produced many of the photographs.

\section{DISCLOSURE STATEMENT}

No potential conflicts of interest are reported by the authors.

\section{REFERENCES}

Archangelsky, M. \& Brand, C. 2014. A new species of Luchoelmis Spangler \& Staines (Coleoptera: Elmidae) from Argentina and its probable larva. Zootaxa, 3779(5): 563-572.

Barr, C.B. 2018. Amazonopsis, an unusual new genus of riffle beetle from South America with two new species (Coleoptera, Elmidae, Elminae). ZooKeys, 803: 71-92.

Benetti, C.J.; Michat, M.C. \& Archangelsky, M. 2018. Chapter 15. Order Coleoptera: Introduction. In: Hamada, N.; Thorp, J.H. \& Rogers, D.C. (Eds.). Keys to Neotropical Hexapoda. Thorp and Covich's Freshwater Invertebrates. 4.ed. London, Academic Press. v. 3, p. 497-517.

Brown, H.P. 1977. Tell-tale larvae. Transactions of the American Microscopic Society, 96(2): 165-170.

Davis, J.A. 1986. Revision of the Australian Psephenidae (Coleoptera): systematics, phylogeny and historical biogeography. Australian Journal of Zoology, Supplementary Series, 119: 1-97.

Dominguez, E. \& Fernández, H.R. 2009. Macroinvertebrados bentónicos sudamericanos. Sistemática y biologia. Tucuman, Arg., Fundacion Muguel Lillo. 656p.

Fernandes, A.S.; Čiampor Jr., F.; Hamada, N. \& Ribera, I. 2013. Discovery of Hintonelmis Spangler (Coleoptera: Elmidae) larvae and preliminary phylogenetic relationships based on COI mDNA sequences. In: Acta Entomologica Musei Nationalis Pragae, 53(2): 896-897. (Fikáček, M; Skuhrovec, J. \& Šípek, P. (Eds.). Abstracts of the immature beetles meeting 2013, 0ctober 3-4, Prague, (zech Republic)

Glaister, A. 1985. Laboratory rearing of Australian elmid larvae (Elmidae: Coleoptera). Australian Society for Limnology Bulletin, Supplement, 10: 51-58.

Glaister, A. 1999. Guide to the identification of Australian Elmidae larvae (Insecta: Coleoptera). Thurgoona, NSW, Cooperative Research Centre for Freshwater Ecology. 48p. (Identification Guide n. 21)

González-Córdoba, M.; Martínez-Román, N.; Archangelsky, M.; Manzo, V. \& Zúniiga, M.C. 2018a. Description of Stenhelmoides mature larva (Coleoptera: Elmidae). In: Congreso Aquatrop Ecosistemas Acuaticos Tropicales. Poster.

González-Córdoba, M.; Martínez-Román, N.; Shepard, W.; Manzo, V. \& Zúñiga, M.C. 2018b. Larval description of Gyrelmis (Coleoptera: Elmidae). In: Congreso Aquatrop Ecosistemas Acuaticos Tropicales. Poster. 
Hamada, N.; Thorp, J.H. \& Rogers, D.C. 2018. Keys to Neotropical Hexapoda. Thorp and Covich's Freshwater Invertebrates. London, Academic Press. v. 3, $795 \mathrm{p}$.

Manzo, V. \& Archangelsky, M. 2008. A key to the known larvae of South American Elmidae (Coleoptera: Byrrhoidea), with a description of the mature larva of Macrelmis saltensis Manzo. Annales de Limnologie, 44(1): 63-74.

Queney, P. 2012. Elmidae de Guyane (Coleoptera): aide à la determination des genres et actualization des genres et espèces cités. Le Coléoptériste, (Suppl. au Bulletin), 4: 82-86.
Segura, M.0.; Valente-Neto, F. \& Fonseca-Gessner, A.A. 2011. Elmidae (Coleoptera, Byrrhoidea) larvae in the state of São Paulo, Brazil: identification key, new records and distribution. ZooKeys, 151: 53-74.

Sonderman, W. 2013. Is the elmid fauna of Colombia strongly marked by Nearctic elements? A remote analysis of genus names provided in 30 recently published benthic macroinvertebrate assessments: (Coleoptera: Byrrhoidea: Elmidae). Dugesiana, 20(2): 251-260.

White, D.S. \& Jennings Jr, D.E. 1973. A rearing technique for various aquatic Coleoptera. Annals of the Entomological Society of America, 66(5): 1174-1176. 